\section{Intestinal and immunological histological parameters of broilers supplemented with commercial probiotic or fungi of the autochthonous microbiota}

\author{
Parâmetros histológicos de frangos de corte suplementados \\ com probiótico comercial ou fungos da microbiota autóctone
}

\author{
Danne Kelle Siqueira Lima' (D), Moisés Sena Pessoa² (1), Emmanuel Arhnold 33 (1), \\ Paulo Ricardo de Sá da Costa Leite ${ }^{4}$ (1) , Angélica Ribeiro Araújo Leonídio ${ }^{5}$ (D), Renato de Lima Santos ${ }^{6}$ (D), \\ Camila Eickstein ${ }^{6}$ (D) , Vilson Matias Pinto ${ }^{7}$ (D) Flávia Oliveira Abrão ${ }^{4}$ (1) \\ 'Undergraduate in Zootechnics. Instituto Federal Goiano - IF Goiano, Campus Ceres, Ceres, GO, Brasil \\ 2Zootechnist, Dr, Professor. Instituto Federal Goiano - IF Goiano, Campus Ceres, Ceres, GO, Brasil \\ ${ }^{3}$ Agronomist, Professor. Universidade Federal de Goiás - UFG, Campus Samambaia, Goiânia, GO Brasil \\ ${ }^{4}$ Zootechnist, Dr., Veterinarian, Professor. Instituto Federal Goiano - IF Goiano, Campus Ceres, Ceres, GO, Brasil \\ ${ }^{5}$ Veterinarian, Dr. Faculdade de Ciências e Educação de Rubiataba, Faculdade de Ceres, Ceres, GO, Brasil \\ ${ }^{V}$ Veterinarian, Dr. Escola de Veterinária, Universidade Federal de Minas Gerais - UFMG, Campus Pampulha, Belo Horizonte, MG, \\ Brasil \\ 7Zootechnist, Mastering in Sustainable Rural Development. Instituto Federal Goiano - IF Goiano, Heítoraí, GO, Brasil
}

\begin{abstract}
This study aimed to assess the histomorphometry of the intestinal portions (duodenum and jejunum) in broilers supplemented with probiotic, and histological parameters of their immune system components. Rhizomucor spp. originated from samples of the intestinal content in Cobb 500 chickens was evaluated; these fungi were submitted to performance assay and selected based on in vitro probiotic characteristics. Complete randomized design was used ( 3 treatments $\times 7$ replicates; 18 birds per experimental unit). One bird at 21 and 42 days of age was sacrificed in each unit and the organs were sampled. In all samples, fixation was conducted followed in order by dehydration and diaphanization; analyses were conducted by light microscopy and histomorphometry, and search was performed for spots indicating the lesion's presence. At 21 days, the duodenum villus height was higher in the group receiving Rhizomucor spp. probiotic, and the jejunum villus height was significantly increased in both the control and Rbizomucor spp. probiotic groups. At 42 days, difference of the duodenum crypt depth was observed in the group receiving commercial probiotic. With regard to the tissue changes of the intestines, spleen, and bursa, no histological alterations were observed at 21 days in all birds (100\%) receiving Rhizomucor spp. probiotic, while alteration of the bursa was observed at 42 days in two animals. Inclusion of probiotic Rhizomucor spp. in the diet of broilers promoted an increase in the height of the villi after 21 days, and any influence of the probiotic was resolved after 42 days of age.
\end{abstract}

Keywords: poultry farming, histomorphometry, Rhizomucor spp., gastrointestinal tract.

\section{Resumo}

Objetivou-se avaliar a histomorfometria das porções intestinais (duodeno e jejuno) de frangos de corte suplementados com probiótico, bem como parâmetros histológicos de órgãos linfóides. O fungo utilizado Rhizomucor spp. é proveniente de amostras do conteúdo intestinal de frangos Cobb 500. Este foi selecionado in vitro quanto características probióticas e encaminhado para ensaio de desempenho. Foi utilizado um delineamento inteiramente ao acaso com três tratamentos e sete repetições e 18 aves por unidade. Uma ave por unidade experimental aos 21 e 42 dias de idade foi sacrificada e, os órgãos foram amostrados. Esse material foi fixado em formol a 10\% tamponado, processado rotineiramente, incluídos em parafina, cortados a $7 \mu$ m e corados pela hematoxilina-eosina (HE). Observou-se aos 21 dias que as aves pertencentes ao grupo probiótico formulado a base de Rhizomucor spp. apresentaram maior altura de vilo no duodeno. Também constatou-se um aumento significativo na altura de vilo do jejuno para o grupo controle e probiótico formulado a base de Rhizomucor spp. Aos 42 dias observou-se, apenas diferença para profundidade de cripta com uso do probiótico comercial para duodeno. Referente as análises das alterações teciduais dos intestinos, baço e bursa aos 21 dias, cem por cento das aves recebendo o fungo

\section{BJ $\mathrm{M}$ \\ Brazilian Journal of Veterinary Medicine}

p-ISSN 0100-2430

e-ISSN 2527-2179

○
How to cite: Lima, D. K. S., Pessoa, M. S., Arhnold, E., Leite, P. R. S. C., Leonídio, A. R. A., Santos, R. L. R., Eickstein, C., Pinto, V. M., \& Abrão, F. O. (2020). Intestinal and immunological histological parameters of broilers supplemented with commercial probiotic or fungi of the autochthonous microbiota. Brazilian Journal of Veterinary Medicine, 42, e101220. http://doi. org/10.29374/2527-2179.bjvm101220

Financial support: UFG, Goiano Federal Institute.

Conflict of interests: No conflict of interests declared concerning the publication of this article.

Received: November 27, 2018.

Accepted: October 10, 2019.

The study was carried out at Institute of Goiano, Campus Ceres production sector, Ceres, GO, Brasil.

\section{*Correspondence}

Flávia Oliveira Abrão Pessoa

Departamento de Zootecnia, Instituto Federal Goiano - IF Goiano, Campus Ceres CEP 76300-000 - Ceres (GO), Brasil E-mail: flavia.abrao@ifgoiano.edu.br
Copyright Lima et al. This is an Open Access article distributed under the terms of the Creative Commons Attribution Non-Commercial License which permits unrestricted non-commercial use, distribution, and reproduction in any medium provided the original work is properly cited. 
Rhizomucor spp. não apresentaram alterações histológicas e aos 42 dias foram observadas alterações na bursa em dois animais. A inclusão do potencial probiótico fúngico Rhizomucor spp. na dieta de frangos de corte aos 21 dias de idade promove maior altura de vilo e aos 42 dias de idade não houve influência.

Palavras-chave: avicultura, histomorfometria, Rhizomucor spp., trato gastrointestinal.

\section{Introduction}

Meat poultry contributes largely to Brazil's economy, and is one of the most modern and efficient livestock sectors. Development of modern poultry farming has resulted from combined adoption and advancement of several factors, including nutrition (Murarolli, 2008); in this sector, use of additives in poultry diet is a main contributing factor of the increase in poultry productivity (Araújo et al., 2007; Bonamigo, 2017).

Antibiotics, probiotics, prebiotics, symbiotics, and exogenous enzymes have been widely used as additives in animal feed, based on their capability to improve the animal's performance and maximize use of diets that are difficult to degrade (Praes, 2013; Manafi et al., 2018). These additives promote beneficial changes of the intestinal microbiota, with trophic effect on the intestinal mucosa, and immunomodulatory stimuli (Nunes et al., 2009).

Knowledge of the gastrointestinal tract as the primary action site of food additives, allows in depth study of probiotics. The digestive tract undergoes maturation during the post-hatching period, particularly that of the thermoregulatory and immune systems (Furlan, 2010).

Resident microorganisms are present in both the small and large intestines, and may vary in type along the gastrointestinal tract. Bacteria, fungi, protozoa, and viruses comprise the microbiota (Andreatti, 2007); among these components, fungi can mechanically break down foods concurrently with their enzymatic action in food degradation, and attain increased surface contact due to their hyphae, which in turn enables activity of the native intestinal microbiota (Pessoa, 2017). Moreover, presence of fungi is closely associated with development and function of the intestines.

Development of the intestinal mucosa proceeds mainly by two cytological events associated with cell renewal, including mitotic divisions of totipotent cells at the crypt and along the villi and cell loss due to normal flaking process at the apex of the villi (Rocha et al., 2016). Balance of these two processes is based on a constant rate of cell renewal and the associated digestive and intestinal absorption capacity (Pelicano et al., 2007).

The villus density varies with the anatomic parts of the small intestine, and the number of the villi declines at 10 days of age onward. Nevertheless, this phenomenon indicates dynamic development of the villus instead of reduction in absorptive capacity of the gut. The number of the villi per unit area decreases as a function of age, and broilers achieve greater reduction of the number than layers (Yamauchi \& Ishiki, 1991; Tellez et al., 2006).

The villus plays a crucial role in metabolism, especially through its apical cells that mediate transepithelial transport of nutrients produced by food digestion; in addition, villus height is directly correlated with intestinal health, and crypt depth (CD) is an indicator of cellular proliferation that allows tissue renewal by compensation for cell loss at the apex of the villus (Boaro, 2009; Pluske et al., 1997).

The mechanism of action of probiotics may include production of antimicrobial substances and organic acids, and protection of the villus and absorptive surfaces (Breda et al., 2010). Probiotics can provide birds with benefits including positive changes of the intestinal microbiota, activity of the immune system, and microenvironment of the intestinal epithelium, which increase the efficiency of nutrient absorption and prevent fixation and multiplication of pathogens in the intestinal mucosa, and consequently, improve overall performance of the species (Fernandes, 2012; Paixão, 2016).

Based on these facts, this study aimed to assess the histomorphometry of the intestinal parts (duodenum and jejunum) in broilers supplemented with probiotics, and histological parameters of the lymphoid organs including the spleen and bursa. 


\section{Materials and methods}

Fungal isolates used in the present study were the same as those obtained in a previous study (Pessoa, 2017) through sampling in October, 2016 from the small and large intestines of $12 \mathrm{Cobb}$ 500 broiler chickens of average age of 42 days; those birds belonged to the Institute of Goiano, Campus Ceres production sector, and were managed in masonry houses, and fed a basal diet consisting mainly of corn and soybean meal under temperature and humidity control, with pendular drinkers and tubular feeders.

The isolates were characterized in vitro at the Microbiology laboratory of the Federal Institute of Goiano, Campus Ceres; for probiotic profile of each isolate, tests of mycotoxin production, resistance to bile salts, and $\mathrm{pH}$ and hydrochloric acid of the digestive tract, antagonism with enterozoonotic bacteria, and species identification with molecular biology technique were performed; as a result, Rhizomucor spp. confirmed by 99\% similarity in Blast ${ }^{\oplus}$ was selected, and the isolate was grown on a large scale for use in the present study.

An appropriate strain was submitted for parallel in vivo performance testing at the Federal Institute of Goiano, poultry sector. After supplementation with the probiotic strain for different study periods, the birds were sacrificed and the organs (spleen, bursa and intestines) were collected for evaluation; the experimental performance period was 42 days (pre-initial: 1 to 7 days, initial: 8 to 21 days, growth: 22 to 35 days, and final: 36 to 42 days). Complete randomized design was used to evaluate three treatments as follows: T1: basal diet without probiotic; T2: basal diet with commercial probiotic; T3: basal diet with selected fungal strain of Rhizomucorspp. The experiment was replicated seven times, with 18 birds in each repetition, which yielded a total of 378 birds and 21 experimental units.

Test probiotic $\left(10^{11}\right.$ spores per $\left.\mathrm{mL}\right)$ was sprinkled twice daily in the feed, and commercial probiotic (Colostrum Mix ${ }^{\circledast}$ ) was added during preparation of the feed (100 g/ton); the feed was formulated with corn and soybean following the recommendations of Rostagno et al. (2011).

One bird per experimental unit was sacrificed by cervical dislocation at 21 and 42 days of age, which yielded seven birds per treatment, and their organs (spleen, bursa, and intestines) were collected. The duodenum fragments at the flexion of the pancreas and jejunum at the level just before Meckel's diverticulum were opened longitudinally, and the ends were fixed with a piece of Styrofoam. The tissues were fixed in 10\% buffered formalin and sent to the Federal University of Minas Gerais Histopathology and Immunohistochemistry Laboratory. At that facility, the tissues were processed in a routine manner, embedded in paraffin, cut to $7-\mu \mathrm{m}$ thickness, and stained with hematoxylin-eosin (HE); the sections were analyzed by light microscopy according to the method of Eto et al. (2015), and histomorphometry including VH (villus height) and CD (crypt depth) using Image J 1.45 software.

The VH was measured from the apex of the villus to the base of the villus-crypt junction, and CD was defined as invagination of the crypt relative to the adjacent villi; twenty readings each per slide were obtained for the two parameters in each tissue fragment, which yielded 140 readings per treatment. In addition, the relationships between villus height and crypt depth (VH / CD) were calculated. All acquired images were digitalized in a Leica DM 4000 B optical microscope coupled to a microcomputer.

For histomorphometry data, exploratory analysis (normality and homoscedasticity) was conducted with Shapiro-Wilk and Bartlett test, and subsequently, ANOVA followed by means test (Tukey at $5 \%$ significance) was performed using $\mathrm{R}^{\circledR}$ statistical software version 3.3.0. Presence or absence of alterations in the evaluated tissues was examined using descriptive statistics.

The study protocol was approved by the Animal Use Ethics Committee (CEUA) of the Federal University of Goiás, and (Approval number: 077/16).

\section{Results}

Mean values of the duodenum and jejunum VH, CD, and villus:crypt ratio at 21 and 42 days of age are shown in Tables 1 and 2, respectively.

The villus height in the duodenum was significantly higher in birds of the test probiotic group with T3 $(\mathrm{P}<0.05)$ than in those of the commercial probiotic group with $\mathrm{T} 2$ and no probiotic feed group with T1 (Table1). Significant increase in the jejunum villus height was observed in T1 and T3. 
Table 1. Mean villus height (VH), crypt depth (PC) and Villus:Crypt ratio of the duodenum and jejunum in 21-day-old chickens receiving diets with or without probiotic.

\begin{tabular}{cccc}
\hline & \multicolumn{3}{c}{ 21 days } \\
\cline { 2 - 4 } Treatments & VH $(\mu \mathrm{m})$ & Dodenum & Villus:Crypt \\
\cline { 2 - 4 } & $1145.80 \mathrm{ab}$ & $324.45 \mathrm{a}$ & $3.57 \mathrm{ab}$ \\
\cline { 2 - 4 } T1 & $692.99 \mathrm{~b}$ & $228.97 \mathrm{a}$ & $2.98 \mathrm{~b}$ \\
T2 & $1367.90 \mathrm{a}$ & $275.46 \mathrm{a}$ & $5.11 \mathrm{a}$ \\
\hline \multirow{2}{*}{ Treatments } & & Jejunum & Villus:Crypt \\
\cline { 2 - 4 } & VH $(\mu \mathrm{m})$ & CD $(\mu \mathrm{m})$ & $2.92 \mathrm{a}$ \\
\hline T1 & $873.45 \mathrm{a}$ & $204.56 \mathrm{a}$ & $3.76 \mathrm{a}$ \\
T2 & $572.88 \mathrm{~b}$ & $207.40 \mathrm{a}$ & $286.16 \mathrm{a}$ \\
\hline
\end{tabular}

T1, without probiotic; T2, with commercial probiotic; T3, with probiotic formulated from Rhizomucor spp. a, b: The means in the column are statistically different at 5\% significance level by Tukey test.

Table 2. Mean villus height (VH), crypt depth (PC), and Villus:Crypt ratio of the duodenum and jejunum in 42-day-old chickens receiving diets with or without probiotic.

\begin{tabular}{cccc}
\hline & \multicolumn{3}{c}{ 42 days } \\
\cline { 2 - 4 } Treatments & DH $(\mu \mathrm{m})$ & Duodenum & Villus:Crypt \\
\cline { 2 - 4 } & $1093.65 \mathrm{a}$ & $349.35 \mathrm{a})$ & $3.12 \mathrm{a}$ \\
\cline { 2 - 4 } T1 & $1059.93 \mathrm{a}$ & $278.20 \mathrm{~b}$ & $3.85 \mathrm{a}$ \\
T2 & $1257.80 \mathrm{a}$ & $380.55 \mathrm{a}$ & $3.36 \mathrm{a}$ \\
\hline \multirow{2}{*}{ T3 } & & Jejunum & Villus:Crypt \\
\hline Treatments & VH $(\mu \mathrm{m})$ & CD $(\mu \mathrm{m})$ & $3.51 \mathrm{a}$ \\
T2 & $1031.71 \mathrm{a}$ & $305.97 \mathrm{a}$ & $3.14 \mathrm{a}$ \\
T3 & $1017.34 \mathrm{a}$ & $329.47 \mathrm{a}$ & $359.46 \mathrm{a}$ \\
\hline
\end{tabular}

$\mathrm{T} 1$, without probiotic; $T 2$, with commercial probiotic; $T 3$, with probiotic formulated from Rhizomucor spp. a, b: The means in the column are statistically different at $5 \%$ significance level by Tukey test.

Regarding $\mathrm{CD}$, no significant difference of the value ( $>>0.05$ ) was observed for the duodenum and jejunum. The villus:crypt ratio was highest $(\mathrm{P}<0.05)$ for the duodenum in $\mathrm{T} 3$ versus the other treatments, and no significant difference of that was obtained for the jejunum among the different treatments $(\mathrm{P}>0.05)$.

At 42 days of age (Table 2), lower duodenal CD was observed in the commercial probiotic group with T2 $(\mathrm{P}<0.05)$, while the other variables were similar among the groups $(\mathrm{P}>0.05)$, indicating that probiotic effects on the intestinal epithelium do not persist in adult birds, which affects the absorptive capacity and production parameters.

At 21 days, no histological alterations of the intestines, spleen, and bursa were observed in any bird (100\%) of the Rhizomucor spp. probiotic group; whereas, at 42 days, alterations of the bursa were observed in two birds of this group, of which, one bird showed slight reduction in cellularity in the lamina and lymphoid follicles in multifocal areas, and the other bird showed moderate multifocal hemorrhage in the adjacent adipose tissue, with clot adherence (Figure 1).

In T3, no changes of the bursa were observed in all birds at 21 days of age. In contrast, changes of the bursa were observed in two birds at 42 days of age, of which, one showed multifocal moderate 


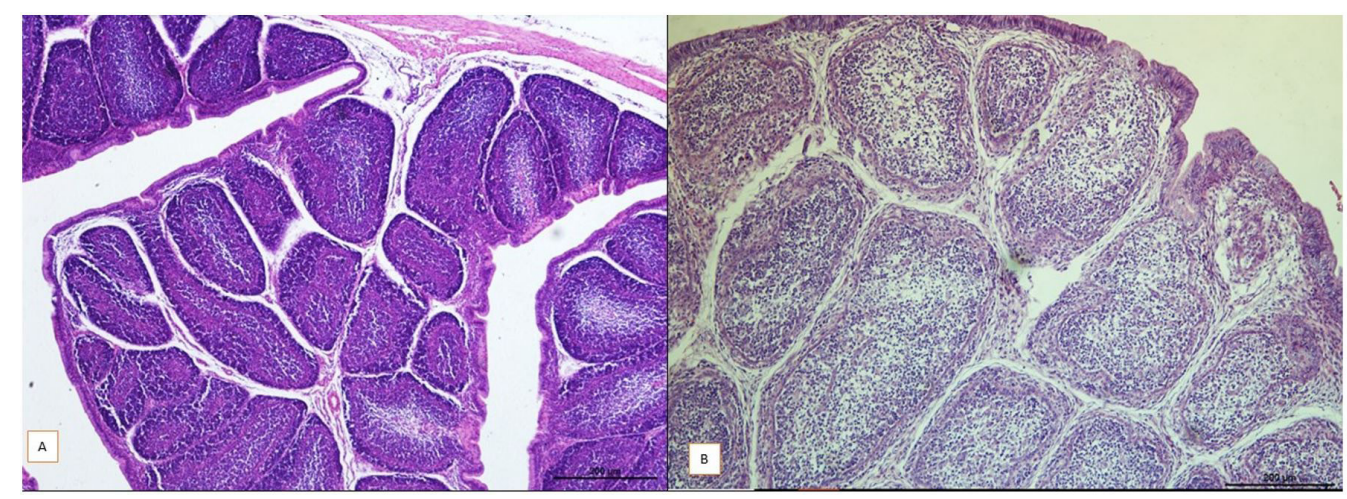

Figure 1. Bursa histology of 21 and 42 days old birds receiving Rhizomucor spp. in the diet. A: Normal bursa of 21-day-old birds, B: Bursa with slight reduction in cellularity in the 42-day-old lymphoid follicles. (scale: $200 \mu \mathrm{m})$

reduction of cellularity at the peripheral zone of the follicles, and the other showed intense focal hemorrhage, with necrotic cells and cellular debris, and numerous clustered punctate structures compatible with bacterial colonies within the follicle. Acellular, amorphous, and brownish material compatible with hemosiderin was present in discrete to moderate multifocal areas in the former sample, while dilation of the follicles and filling of those with mucinous content was observed in the latter sample.

In T2, alterations of the bursa involving diffuse, discrete, and diffuse inflammatory lymphocyte infiltrate in the serosa and moderate focal extensive hemorrhage over the serosa interspersed with adjacent adipose tissue were observed in two birds at 21 days of age.

At 21 days, in all treatment groups, no histological changes in the spleen were observed (Figure 2); whereas, at 42 days in T3, splenic alterations were observed in three birds, of which, one each

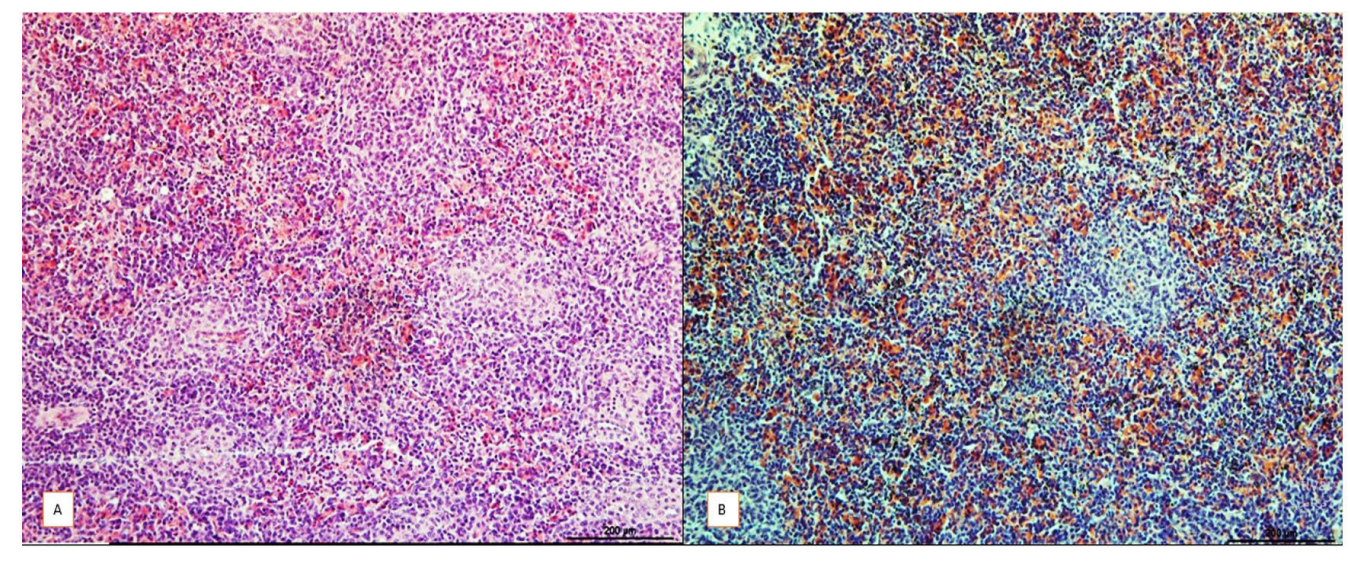

Figure 2. Spleen histology of 21 and 42-year-old birds receiving Rhizomucor spp. in the diet. A: Normal spleen $(200 \mu \mathrm{m})$, B: Spleen with diffuse white pulp depletion, moderate with red pulp hyperplasia. (scale: $200 \mu \mathrm{m})$.

showed brownish acellular, discrete, and hemosiderin-compatible foci, slight diffuse increase of the red pulp, and moderate diffuse hyperplasia of the white pulp that extended into the red pulp.

In the control group with $\mathrm{Tl}$, splenic alteration was observed in only one bird, which showed extensive hemorrhage and slight, diffuse reduction of the white pulp and red pulp hyperplasia. In the commercial probiotic group with T2, splenic alteration was observed in two animals, of which, one each showed diffuse, moderate hyperplasia of the red pulp, with diffuse and discrete lympholysis, and extensive focal lymphocytic, and heterophilic inflammatory infiltrate.

In all treatment groups at 21 days, no histological changes of the intestinal parts were observed, while at 42 days, increased reaction to injury or inflammation in these compartments was observed in the birds of the different groups. Multifocal bleeding was observed in one bird of 
the Rhizomucor spp. probiotic group, normal range of the values was obtained in all birds of the control group with $\mathrm{T1}$, and slight bleeding in the serosa with a small clot attached to the adjacent area was observed in one bird of the probiotic group with $\mathrm{T} 2$.

\section{Discussion}

Optimum height of the intestinal villi and shallow $\mathrm{CD}$, which together yield a high villus:crypt ratio, are considered desirable factors (Nabburs, 1995). The enterocytes are present in larger numbers in an intestinal tract with higher villus:crypt ratio, which contributes to better digestive efficiency. Lower value of the villus:crypt ratio is an indicator of villus destruction (Santos, 2010); nevertheless, Pluske et al. (1997) reported that lower CD might be associated with cell proliferation that allows tissue renewal. Based on these findings, investigators should study a combination of those variables.

Another group investigating this issue (Pessoa, 2017) reported more significant weight gain in birds receiving any type of probiotic for up to 14 days (performance periods: 1 to 7 days and 8 to 14 days), but no change of the average weight gain from 21 days to 42 days. Moreover, the birds supplemented with test fungus Rhizomucor spp. showed similar feed consumption for up to 14 days as compared to the birds on a control diet, which indicates that similar amount of feed between the groups with and without probiotic achieved the top amount of weight gain during the early period; hence, probiotics should be considered treatment of choice in young birds based on high feed conversion of 1.47 .

In our study, birds supplemented with test fungus Rhizomucor spp. attained higher villus:crypt ratio for up to 21 days, which can contribute to higher digestive efficiency and, consequently, better feed conversion and weight gain; our result highlights the probiotic effects of Rhizomucor spp. at initial production phase.

Pelicano et al. (2005) studied the effects of supplementation of two probiotics and two prebiotics on the intestinal morphology of birds at 21 days of age, and reported similar histomorphometric results to those of our study: higher duodenum villus height and smaller CD for both probiotics and prebiotics compared to those for the control without growth promoter.

Ramos et al. (2011) evaluated the production performance and histomorphometry of the small intestine segments in broilers at 21 days of age supplemented with different growth enhancers (probiotics, prebiotics, and antibiotics); in corroboration with the previous studies, they reported additive interference on the duodenum villus height, but no differences in the duodenum and jejunum CD among the different growth enhancers compared to the control treatment.

Mezalira et al. (2014) evaluated enteric morphometry (VHand CD) in broiler chicks supplemented with or without Lactobacillus spp. probiotic and/or betaglucan prebiotic at 1 to 7 days of age; those authors reported no group-wise difference in the parameters of the duodenum and jejunum in the small intestine.

Bueno et al. (2012) evaluated the influence of probiotic supplementation on the intestinal morphology of birds; they reported a significant treatment effect at 42 days of age in birds supplemented with probiotics, and the result of their study was confirmed in the later studies. Moreover, those authors reported that probiotic added in the diet caused a reduction of the duodenum CD as compared to that by a control diet without probiotic, which conflicts with the result of lower duodenum villus height in the control group without probiotic versus the treatment group with probiotics of Pelicano et al. (2003).

Nunes et al. (2009) compared the performance and intestinal morphology of broilers fed diets containing probiotic composed of Lactobacillus acidophilus, Streptococcus faecium and Bifidobacterium bifidum and mananoligosaccharide prebiotic derived from the cell wall of Saccharomyces cerevisiae and reported no benefits from probiotic supplementation, which conflicts with the results of the duodenum and jejunum villus height and CD at 42 days of age for broilers in the present study. Ribeiro et al. (2007) evaluated supplementation of prebiotic, probiotic, and symbiotic in birds challenged with Salmonella enteritidis, and reported no differences in the parameters of villus height and $\mathrm{CD}$ among the treatments.

Okamoto et al. (2009) evaluated histopathology of the intestinal mucosa in broilers challenged with Salmonella Enteritidis and Lactobacillus spp. at 21 days and reported that there were no apparent lesions in the gastrointestinal tract; with regard to treatment with Lactobacillus spp. 
alone, they reported some mild injury with mild edema that resolved quickly, while with regard to that with Salmonella Enteritidis they reported most pronounced lesions of severe necrosis, severe edema, and congestion.

Azza et al. (2018) evaluated the tissue changes of chicks challenged with Escherichia coli, and reported some focal leukocyte infiltration with degenerative changes in the cecum for birds of the probiotics and antibiotics groups, and no changes for those of the control group without Escherichia coli challenge.

In this context, Teixeira et al. (2007) evaluated the efficacy of betaine against Eimeria acervulin infection in broilers, and reported initial development of the lesions with small whitish plaques and progression of those to yellowish or fully yellow lesions in the duodenum with extension to the jejunum and ileum in some cases.

\section{Conclusion}

Inclusion of fungal probiotic potential candidate Rhizomucor spp. in the diet of broilers promoted an increase of the villus height and villus:crypt ratio at 21 days of age, which indicates higher efficiency of the digestive tract and, consequently, better feed conversion at the initial phase of poultry farming. Rhizomucor spp. probiotic supplement produced no change in the duodenum and jejunum villus height, $\mathrm{CD}$, and villus:crypt ratio at 42 days of age. Moreover, it produced no tissue changes in the intestines, spleen, and bursa at 21 days, while it promoted changes in the bursa of two animals at 42 days. Studies in addition to the few available relevant studies are needed to clarify the mechanism of action involved in alteration of these parameters by the different treatments.

\section{Acknowledgements}

Capes, FAPEG, UFG, UFMG and Goiano Federal Institute.

\section{References}

Andreatti, F. R. L. (2007). Alimentos funcionais na produção avícola. Saúde aviária e doenças. São Paulo. Rocca Ltda, 23, 41-51.

Araújo, J. C., Silva, J. H. V., Amâncio, A. L. L., Lima, M. T., \& Lima, C. B. (2007). Uso de aditivos na alimentação de aves. Acta Veterinaria Brasilica, 1, 69-77.

Azza, A.EL-S., Hussien, M.D., El-Shaymaa, E.A.I. \& Abd, E.M. (2018). Pathogenicity of Escherichia coli 0157 in comercial broiler chickens. Beni-Suef University Journal of Basic and Applied Sciences, 10, 10-16.

Boaro, M. (2009). Morfofisiologia trato intestinal fisiologia frango: morfofisiologia do trato intestinal. Avicultura. Retrieved in 10 October 2018, from https://pt.engormix.com/avicultura/artigos/morfofisiologia-trato-intestinalfisiologia-frango-t36791.htm

Bonamigo, D. V. (2017). Associação de cantaxantina e 25-hidroxicolecalciferol na alimentação de frangos de corte (Dissertação). Universidade Federal de Santa Maria, Centro de Ciências Rurais, Santa Maria. Retrieved in 20 JANUARY 2020, from https://repositorio.ufsm.br/handle/1/11549

Breda, A. L., Pereira, M. M., Oliveira, A. P., Batista, P. B., Farias, P. G., Dias, D. L. S., Macêdo, J. F., Lima, K. S., \& Brandão, R. K. C. (2010). Manipulação de microrganismos intestinais em monogástricos: revisão de literatura. Pubvet. 4(1) 710-716.

Bueno, R., Albuquerque, R., Murarolli, V. D. A., Aya, A. H., \& Raposo Bordin, R. A. (2012). Efeito da influência de probiótico sobre a morfologia intestinal de codornas japonesas. Brazilian Journal Veterinary Research Animal Science, 49(2), 111-115. http://dx.doi.org/10.11606/issn.2318-3659.v49i2p111-115.

Eto, S. F., Fernandes, D. C., Gonçalves, A. M., Santos, L. F. J., Moraes, J. R. E., Junior, J. M. P., \& Moraes, F. R. (2015). Histologia dos órgãos e tecidos linfóides de galinhas poedeiras White Leghorn. Revista Portuguesa de Ciências Veterinária, 110, 74-78.

Fernandes, B. C. S. (2012). Integridade intestinal e desempenho de frangos de corte suplementados com probióticos, prebióticos e ácidos orgânicos (Dissertação). Universidade Estadual Paulista, Botucatu. Retrieved in 18 OCTOBER2019, from https://repositorio.unesp.br/bitstream/handle/11449/99585/fernandes_bcs_me_botfmvz. pdf?sequence $=1$

Furlan, R. L. (2010). Aspectos fisiológicos da utilização de probióticos e prebióticos visando a saúde intestinal. Memórias Associacion de Médicos Veterinarios Especialistas en Avicultura del Ecuador. Quito: AMEVEA-E. Retrieved in 18 OCTOBER 2019, from https://updoc.site/download/aspectos-fisiologicos-da-utilizaao-de-amevea_pdf

Manafi, M., Hedayati, M., \& Mirzaie, S. (2018). Probiotic Bacillus species and Saccharomyces boulardii improve performance, gut histology and immunity in broiler chickens. South African Journal of Animal Science, 48(2), 379-389. http://dx.doi.org/10.4314/sajas.v48i2.19. 
Mezalira, T.S., Otutumi, L.K., Junior, R.P., Amaral, F.G.P. \& Suenaga, S.S. (2014). Morfometria do intestino delgado de frangos de corte recebendo dietas suplementadas ou não com probiótico e/ou prebiótico. Enciclopédia biosfera, 10(18): 2246-2256.

Murarolli, V. D. A. (2008). Efeito de prebiótico, probiótico e simbiótico sobre o desempenho, morfologia intestinal e imunidade de frangos de corte (Dissertação). Universidade de São Paulo, São Paulo. Retrieved in 18 OCTOBER 2019, from http://www.teses.usp.br/teses/disponiveis/10/10135/tde-23012009-133435/publico/ Vinicius_Diogo_Azevedo_Murarolli.pdf

Nabburs, M. J. A. (1995). Microbiological, structural and functional changes of the small intestine of pigs at weaning. Pig News and Information, 16, 93-97.

Nunes, A. D., Vaz, A. C. N., Raspantini, L. E., Silva, E. M., \& Alburquerque, R. (2009). Desempenho e morfologia intestinal de frangos de corte alimentados com rações contendo aditivos alternativos a antimicrobianos. Brazilian Journal vet. Reserach Animal Science, 46, 500-506.

Okamoto, A. S., Filho, R. L. A., Lima, E. T., \& Noujaim, J. C. (2009). Histopatologia da mucosa intestinal de pintos tratados com Lactobacillus spp. e desafiadas com Salmonella enterica, subespécie enterica, sorotipo Enteritidis. Ciência Animal Brasileira, 10, 568-573.

Paixão, L. A. (2016). A colonização da microbiota intestinal e sua influência na saúde do hospedeiro. Universitas. Ciências da Saúde, 14, 85-96.

Pelicano, E. R. L., Souza, P. A., Souza, H. B. A., Figueireido, D. F., \& Amaral, C. M. C. (2005). Intestinal mucosa development in broiler chickens natural growth promoters. Revista Brasileira de Ciência Avícola, 7(4), 221-229. http://dx.doi.org/10.1590/S1516-635X2005000400005.

Pelicano, E. R. L., Souza, P. A., Souza, H. B. A., Figueireido, D. F., \& Amaral, C. M. C. (2007). Morphometry and Ultra-structure of the Intestinal Mucosa of Broilers Fed Different Additives. Revista Brasileira de Ciência Avícola, 9(3), 173-180. http://dx.doi.org/10.1590/S1516-635X2007000300006.

Pelicano, E. R. L., Souza, P. A., Souza, H. B. A., Oba, A., Norkus, E. A., Kodawarac, L. M., \& Lima, T. M. A. (2003) Intestinal Mucosa Structure and Ultrastructure in Broilers fed with Diets supplemented with different Probiotics. RPCV, 98(547), 125-134

Pessoa, M. S. (2017). Seleção e caracterização de fungos filamentosos provenientes da microbiota endógena intestinal de frangos de corte para utilização como potenciais probióticos na nutrição avícola (Tese de doutorado). Universidade Federal de Goiás, Escola de Veterinária e Zootecnia, Goiânia. Retrieved in 18 OCTOBER 2019, from https://sigaa.sistemas.ufg.br/sigaa/public/programa/defesas.jsf?lc=pt_BR\&id=3192

Pluske, J. R., Hampson, D. J., \& Williams, I. H. (1997). Factors influencing the structure and function of the small intestine in the weaned pig: a review. Livestock Production Science, 51(1-3), 215-236. http://dx.doi.org/10.1016/ S0301-6226(97)00057-2.

Praes, M. F. F. M. (2013). Probiótico e enzimas em dietas de frangos de corte: desempenho, características da cama e excretas e produção de biogás (Tese de doutorado). Universidade Estadual Paulista, Faculdade de Ciências Agrárias e Veterinárias. Retrieved in 18 OCTOBER 2019, from https://repositorio.unesp.br/bitstream/ handle/11449/106621/000751255.pdf?sequence=1

Ramos, L. S. N., Lopes, J. B., Silva, S. M. M. S., Silva, F. E. S., \& Ribeiro, M. N. (2011). Desempenho e histomorfometria intestinal de frangos de corte de 1 a 21 dias de idade recebendo melhoradores de crescimento. Revista Brasileira de Zootecnia, 4O(8), 1738-1744. http://dx.doi.org/10.1590/S1516-35982011000800017.

Ribeiro, A. M. L., Vogt, L. K., Canal, C. W., Cardoso, M. R. I., Labres, R. V., Streck, A. F., \& Bessa, M. C. (2007). Effects of prebiotics and probiotics on the colonization and immune response of broiler chickens challenged with Salmonella Enteritidis. Revista Brasileira de Ciência Avícola, 9(3), 193-200. http://dx.doi.org/10.1590/ S1516-635X2007000300009.

Rocha, P. M. C., Barros, M. E. G., \& Evencio-Neto, J. (2016). Análise morfométrica da parede intestinal e dinâmica de mucinas secretadas no jejuno de frangos suplementados com probiótico Bacillus subtilis cepa C3102. Pesquisa Veterinária Brasileira, 35(4), 344-348. http://dx.doi.org/10.1590/50100-736X2016000400010.

Rostagno, H. S., Albino, L. F. T., Donzelle, J. F., Gomes, P. C., Ferreira, A. S., Oliveira, R. F. D., Lopes, D. C., Barreto, S. L. T., \& Euclides, R. F. (2011). Tabelas brasileiras para aves e suínos. Composição de alimentos e exigências nutricionais. Viçosa. UFV, 3, 1-252.

Santos, I. I. (2010). Efeitos de probiótico, óleos essenciais e enzimas em parâmetros produtivos e sanitários de frangos de corte (Doutorado em Produção Animal). Universidade Federal do Rio Grande do Sul, Porto Alegre. Retrieved in 18 OCTOBER 2019, from http://repositorio.utfpr.edu.br/jspui/bitstream/1/2800/1/DV_PPGZO_M_ Santos\%2C\%2OJos\%C3\%A9\%20Rodolfo\%2Odos_2013.pdf

Teixeira, M., Niang, T. M. S., Gomes, A. V. C. G., Filho, W. L. T., \& Lopes, C. W. G. (2007). Alterações clínicas e patológicas durante a infecção experimental com Eimeira acervulina em frangos de cortes suplementados com betaína. Revista Brasileira de Ciência Veterinária, 14(3), 127-132. http://dx.doi.org/10.4322/rbcv.2014.248.

Tellez, G., Higgins, S. E., Donoghue, A. M., \& Hargis, B. M. (2006). Digestive physiology and the role of microorganisms. Journal of Applied Poultry Research, 15(1), 136-144. http://dx.doi.org/10.1093/japr/15.1.136.

Yamauchi, K. E., \& Ishiki, Y. (1991). Scanning electron microscopic observations on the intestinal villi in growing White Leghorn and broiler chickens from 1 to 30 days of age. British Poultry Science, 32(1), 67-78. http://dx.doi. org/10.1080/00071669108417328. PMid:2049631. 